\title{
THE AVOIDABLE EVILS OF "ALL SUMS" LIABILITY FOR LONG-TAIL INSURANCE COVERAGE CLAIMS
}

Jan M. Michaels, *William D. Ellison** \& Sridevi R. Krishnan***

\section{INTRODUCTION}

Most events covered by insurance happen at a fixed point in time. Accordingly, in the typical context, timing issues relating to coverage under commercial general liability (CGL) insurance policies relate to whether the bodily injury or property damage happened during a particular policy period. This question is usually described as whether the policy is "triggered." In the context of the usual claim, a court simply determines when the injury or damage took place, and whether the relevant policy was in effect at that time.

Environmental, toxic tort, and some products liability claims, however, present more complex timing issues. These types of claims often involve progressive injuries or damage happening over substantial timeframes. In the insurance industry, such losses are often called "longtail" claims. Many long-tail claims involve injury or damage spanning multiple policy years. A court considering timing issues relating to coverage for such claims is faced not only with the challenge of determining which policies are triggered, but also with a far more complicated question: whether and how to allocate the damages between the relevant insurers and between the insurers and the policyholder.

The most common approach used to determine how to allocate longtail losses among multiple triggered policy years is often called "pro rata

\footnotetext{
* Shareholder, Michaels, Schulwolf \& Salerno, P.C., Chicago, Illinois, handling complex commercial and insurance coverage litigation cases including environmental exposure, allocation, products liability, and mass tort. J.D., University of Notre Dame Law School; B.A., State University of New York at Albany.

** Senior Attorney, Michaels, Schulwolf \& Salerno, P.C., Chicago, Illinois and Kansas City, Missouri, more than 25 years handling complex insurance coverage disputes in state and federal courts throughout the country. J.D., magna cum laude, Northern Illinois University College of Law. *** Associate, Michaels, Schulwolf \& Salerno, P.C., Chicago, Illinois. J.D., Loyola University Chicago School of Law; B.A., Benedictine University.
} 
by time-on-the-risk allocation."1 Under the pro rata approach, the relevant damages are simply spread equally across all of the years in which the continuous injury or damage took place. ${ }^{2}$ However, some jurisdictions have taken a completely different tack, known as "all sums" liability. Under the all sums scheme, each policy year during any of the years in which the continuous injury or damage took place is deemed liable to pay for the entire loss up to the limits of the insurance available in that year. ${ }^{3}$ The policyholder is then free to choose any triggered policy period to respond to the claim, leaving the selected insurers to pursue contribution from other carriers whose policies also were triggered. ${ }^{4}$

Courts applying the all sums approach typically rely on the isolated phrase "all sums," which appears in the insuring agreement in many CGL policies. Those insuring agreements commonly state that the insurer will "pay on behalf of the insured all sums which the insured shall become legally obligated to pay as damages because of bodily injury or property damage to which this insurance applies caused by an occurrence." Courts applying this approach ignore the phrase "bodily injury or property damage to which this insurance applies" in the insuring agreement, as well as all of the other policy language that this phrase brings into play. ${ }^{6}$ Under all sums liability, each triggered policy is liable for "all sums which the insured shall become legally obligated to pay" for the claim up to its limits of liability, including amounts due to injury or damage that happened outside of the period of the policy. ${ }^{7}$

There is a multiplicity of reasons why it is improper for a court to ignore the plain language of these policies in order to apply the all sums approach. Without purporting to be comprehensive, this Article

1. 3-22 New Appleman on Insurance Law Library Edition $§ ~ 22.03$ [2] (Jeffrey E. Thomas ed.) (2015).

2. Id.

3. Thomas M. Jones, An Introduction to Insurance Allocation Issues in Multiple-Trigger Cases, 10 VILL. ENVTL. L.J. 25, 38 (1999).

4. Id. at 37-38.

5. Andrew Weiner \& Joseph Saka, The Basics of Commercial General Liability Policies, AM. BAR Ass'N,

http://www.americanbar.org/groups/young_lawyers/publications/the_101_201_practice_series/the_b asics_of_commercial_general_liability_policies.html. (emphasis added) (last visited Oct. 6, 2015).

6. See infra Part I.B.

7. See, e.g., Keene Corp. v. Ins. Co. of N. Am., 667 F.2d 1034, 1049-50 (D.C. Cir. 1981); Hercules, Inc. v. AIU Ins. Co., 784 A.2d 481, 493-94 (Del. 2001); Allstate Ins. Co. v. Dana Corp., 759 N.E.2d 1049, 1058 (Ind. 2001); Goodyear Tire \& Rubber Co. v. Aetna Cas. \& Sur. Co., 769 N.E.2d 835, 841 (Ohio 2002); J.H. Fr. Refractories Co. v. Allstate Ins. Co., 626 A.2d 502, 507-08 (Pa. 1993); Am. Nat'l Fire Ins. Co. v. B \& L Trucking \& Constr. Co., 951 P.2d 250, 256-57 (Wash. 1998); Plastics Eng'g Co. v. Liberty Mut. Ins. Co., 759 N.W.2d 613, 616 (Wis. 2009). 
highlights the following problems with those decisions that have ignored cardinal principles of contract construction to reach the all sums result:

(1) All sums liability is fundamentally inconsistent with a continuous trigger for long-tail claims;

(2) A court must improperly ignore the policy period limitations in CGL policies to impose all sums liability;

(3) All sums liability violates the parties' reasonable expectations; and

(4) All sums liability unjustly enriches policyholders.

In addition to the impropriety of ignoring the above points, courts deciding to apply the all sums approach generally do not fully appreciate the magnitude and complexity of the follow-on litigation that will result from adopting that approach. Some of the more prominent conundrums that these courts will have to resolve in this context are:

(1) how to construe and how to apply the "prior insurance/noncumulation clauses" that appear in many CGL policies in the context of all sums liability; ${ }^{8}$

(2) how to construe, reconcile and apply the "other insurance" clauses found in CGL policies under the all sums scheme; ${ }^{9}$

(3) how to construe and apply subrogation clauses in the relevant policies, and how to apply equitable contribution principles as between insurers; and

(4) how settlements that the policyholder may have reached previously with some of its insurers impact reallocation among the remaining insurers, and how to address the potentially contentious discovery disputes that may arise from the need to ascertain the terms of the pertinent prior settlement agreements.

Accordingly, in addition to discussing the impropriety of the all sums result from a contract construction perspective, this Article also addresses the above issues.

Finally, this Article discusses how the pro rata allocation approach avoids all of the flaws underlying the all sums scheme and the practical problems arising under that scheme. Based on these points, this Article

8. See infra Part III.A.

9. See infra Part III.B. 
concludes that courts should apply pro rata allocation to assigning responsibility for damages arising from long-tail claims.

\section{II. “ALL SUMS” IGNORES CARDINAL PRINCIPLES OF CONTRACT CONSTRUCTION AND UNJUSTLY BENEFITS THE POLICYHOLDER}

As discussed more fully below, all sums liability blatantly disregards the fundamental principles of contract construction governing the interpretation of any insurance policy by enabling a policyholder to hold a single policy year accountable for damages due to injury or damage potentially spanning decades.

First, all sums liability is inconsistent with a continuous trigger theory of liability, which presumes that damage or injury arising from long-tail claims is progressive and indivisible. Although this theory does not provide any means by which to ascertain the amount of damage happening within any given policy period, all sums liability would permit a policyholder to impose liability on an insurer for damages attributable to injury or damage taking place well after the termination of that insurer's policy.

Second, the all sums approach subverts the explicit temporal limitations appearing in CGL policies, which provide that the insurer is not liable for damages arising from damage or injury happening before or after the policy period. As a result, policyholders effectively receive premium-free insurance because insurers are forced to pay for damages that they did not agree to insure.

Third, the all sums scheme violates the doctrine of reasonable expectations applied by some courts, under which ambiguities in an insurance policy are construed against the insurer when the policyholder has an objectively reasonable expectation of coverage. The reason for this is clear: no reasonable policyholder would expect that a single insurance policy would cover all damages stemming from asbestos exposure or environmental contamination happening over the course of several decades.

Lastly, all sums liability is plainly inequitable and results in a windfall to the policyholder. This approach entitles a policyholder to receive premium-free coverage for periods during which it was selfinsured and for injury or damage happening outside of the policy period, in violation of the plain terms of the insurance contract. Numerous courts have recognized the inequities of all sums liability, which ultimately acts to the detriment of the policyholder by forcing insurers to raise premiums. This, in turn, causes insurers to be hesitant to issue policies with generous limits due to the risk that these generous limits 
will cause the insured to select a single policy year to cover the entirety of a loss spanning decades.

\section{A. "All Sums" is Fundamentally Inconsistent with a Continuous Trigger}

It is axiomatic that an insurer's obligation to pay under a CGL policy is contingent on covered injury or damage happening during the policy period. ${ }^{10}$ CGL policies usually contain temporal limitations restricting coverage to bodily injury or property damage or to occurrences that take place during the applicable policy period. ${ }^{11}$ By their express terms, these policies are not intended to insure against all injury or damage- no matter when it happens. ${ }^{12}$ A policyholder purchases a policy to indemnify it for its liability for damage or injuries taking place within a given policy period - not damage or injuries happening outside that period. ${ }^{13}$

Accordingly, the policyholder ordinarily must show that the damage or injury for which it seeks coverage took place while the policy was in effect, as well as the amount of the damages for which it is liable as a result of that damage or injury. The policyholder is entitled to recover the damages for which it is liable up to the policy's limits if the policy was in effect at the time of the damage or injury, and the policy otherwise covers liability for that damage or injury. ${ }^{14}$ However, it is considerably more difficult, if not impossible, to determine how to apportion damages arising from a claim involving bodily injury or property damage spanning long periods of time (such as asbestos bodily injury and environmental property damage claims). Such claims usually do not involve damage or injury happening at a discrete point in time. ${ }^{15}$ The progressive and indivisible nature of the injury or damage involved

10. 7 COUCH ON INSURANCE $\S 102: 2$ (3d ed. 2003) ("It is a time-honored principle that the insurer's obligation to pay is contingent on a covered loss occurring during the policy period.").

11. See Andrew Weiner \& Joseph Saka, The Basics of Commercial General Liability Policies, AM. BAR

http://www.americanbar.org/groups/young_lawyers/publications/the_101_201_practice_series/the_b asics_of_commercial_general_liability_policies.html (last visited Oct. 6, 2015).

12. See 6B J.A. Appleman \& J. Appleman, Insurance LaW AND Practice $\$ 4254$ at 26-27 (Rev. ed. 1979).

13. Olin Corp. v. Ins. Co. of N. Am., 221 F.3d 307, 322-23 (2d Cir. 2000) (citing Michael G. Doherty, Allocating Progressive Injury Liability Among Successive Insurance Policies, 64 U. CHI. L. REV. 257, 270 (1997)).

14. See 7 COUCH ON INSURANCE $§ 102: 2$, supra note 10.

15. See Farmers Mut. Fire Ins. Co. v. N.J. Prop.-Liab. Ins. Guar. Ass'n, Nos. L-0619-09, L1004-09, 2011 WL 2671583, at*8 (N.J. Super. Ct. App. Div. July 11, 2011). 
in such claims has led most jurisdictions to adopt a presumption that the injury or damage is continuous. ${ }^{16}$ This presumption is known as the "continuous trigger" theory. ${ }^{17}$

A policy is "triggered" when a threshold event specified in the policy implicates coverage under the policy. ${ }^{18}$ The fact that a policy has been triggered means that the policy might cover liability arising from the specified event, subject to the policy's other terms, including exclusions in the policy that may bar coverage for the loss, and subject to any other coverage defenses that may apply. ${ }^{19}$ The continuous trigger theory presumes that the injury or damage began at a particular point in time, and took place continuously until an appropriate "end" point. ${ }^{20}$ The purpose of the theory is to relieve the policyholder of the burden that it otherwise would have to show how much of the damages arising from the progressive damage or injury is attributable to the damage or injury that actually took place during the period insured by the policy under which the policyholder seeks coverage. ${ }^{21}$

The continuous trigger theory, however, provides no basis for concluding that any more or less injury or damage took place in any given part of the injury or damage period. One of the principle flaws inherent in the all sums scheme is that it permits the policyholder to "shoehorn" all of the damages due to injury or damage happening during

16. See Pub. Serv. Co. of Colo. v. Wallis \& Cos., 986 P.2d 924, 939 (Colo. 1999) (en banc).

17. See, e.g., Pub. Serv. Co. of Colo., 986 P.2d at 939; N. States Power Co. v. Fid. \& Cas. Co. of N.Y., 523 N.W.2d 657, 662-64 (Minn. 1994); Spaulding Composites Co. v. Aetna Cas. \& Sur. Co., 819 A.2d 410, 415 (N.J. 2003).

18. See Pub. Serv. Co. of Colo., 986 P.2d at 937 n.11.

19. Id.

20. See, e.g., Keene Corp. v. Ins. Co. of N. Am., 667 F.2d 1034, 1045-46 (D.C. Cir. 1981); Broderick Inv. Co. v. Hartford Accident \& Indem. Co., 742 F. Supp. 571, 573 (D. Colo. 1989), rev'd on other grounds, 954 F.2d 601 (10th Cir. 1992); Harleysville Mut. Ins. Co. v. Sussex Cty., 831 F. Supp. 1111, 1124 (D. Del. 1993), aff'd, 46 F.3d 1116 (3d Cir. 1994); Fireman's Fund Ins. Co. v. ExCell-O Corp., 662 F. Supp. 71, 76 (E.D. Mich. 1987); GenCorp, Inc. v. AIU Ins. Co., 104 F. Supp. 2d 740, 749 (N.D. Ohio 2000); Montrose Chem. Corp. v. Admiral Ins. Co., 913 P.2d 878, 880 (Cal. 1995); United States Gypsum Co. v. Admiral Ins. Co., 643 N.E.2d 1226, 1257 (Ill. App. Ct. 1994); Spaulding Composites Co. v. Aetna Cas. \& Sur. Co., 819 A.2d 410, 415 (N.J. 2003); Towns v. N. Sec. Ins. Co., 964 A.2d 1150, 1165 (Vt. 2008); Soc'y Ins. v. Town of Franklin, 607 N.W.2d 342, 346 (Wis. Ct. App. 2000).

21. See, e.g., E. I. du Pont de Nemours \& Co. v. Admiral Ins. Co., No. 89C-AU-99, 1995 WL 654020 , at $* 26$ (Del. Super. Ct. Oct. 27, 1995) (imposition of the continuous trigger theory "alleviated the difficulty of proving when contamination began and how much contamination occurred in each year"); Nat'l Union Fire Ins. Co. v. Rhone-Poulenc Basic Chems. Co., No. 87C-SE11, 1994 Del. Super. LEXIS 722, at*7 (Del. Super. Ct. Apr. 13, 1994) (discussing that the continuous trigger theory arose because "[i]f the quantum of damages is not provable for any particular year, and if the insured is allocated the burden of proof of the extent of damage within each policy period, then coverage paid for will be defeated"). 
the entire continuous trigger period into a single policy period. ${ }^{22}$ Thus, under all sums liability, a policyholder can hold a policy insuring a single year liable for damages spanning multiple years or decades. The flaw in this outcome is made clear when the policy under which the policyholder seeks coverage has a policy period at the beginning or in the middle of the continuous trigger period. In that situation, the all sums approach requires a policy to cover damages due to injury or damage happening well after the policy ceased providing insurance. No court would hold that such a policy must cover damages attributable to injury or damage that clearly began after the policy terminated. Yet all sums liability results in a logically indistinguishable outcome. In this way, all sums is patently inconsistent with the continuous trigger theory; once the theory is applied, no single policy should be held responsible for damage or injury that presumptively took place outside of its policy period, including damage or injury that took place decades later or during uninsured periods. $^{23}$

The continuous trigger theory is a legal fiction that already relieves the policyholder of its burden to establish whether injury or damage happened during each policy period - a burden imposed by the plain meaning of the contract language. This departs from what that language otherwise would require. Courts should not compound the benefit conferred on the policyholder through the continuous trigger accommodation by using that benefit as justification for further abrogating the insurer's right to rely on the plain meaning of its contract language through the imposition of all sums liability.

\section{B. All Sums Liability Impermissibly Ignores the Temporal Limitation in CGL Policies}

Insurance policies are contracts and are subject to the rules of contract construction. ${ }^{24}$ Accordingly, pursuant to the plain language in CGL policies, courts have held that the policyholder bears the initial burden to show that a claim falls within the terms of the policy. ${ }^{25}$ Although the scope of coverage provided by CGL policies may vary, the

\footnotetext{
22. See Jones, supra note 3, at 37-39.

23. See Mayor of Balt. v. Utica Mut. Ins. Co., 802 A.2d 1070, 1104 (Md. Ct. Spec. App. 2002).

24. 1-5 New APPLEMAN ON InSURANCE Law LibraRy Edition $\$ 5.01$ (Jeffrey E. Thomas ed.) (2015).

25. 3-18 New Appleman on Insurance LaW Library Edition § 18.01[2] (Jeffrey E. Thomas ed.) (Library ed. 2015).
} 
policy period is a vital part of these contracts. ${ }^{26}$ Absent an express provision to the contrary, the insurer is not liable for damages arising from bodily injury or property damage happening before or after the policy period. ${ }^{27}$ Thus, insurers calculate the premium for these policies based on an assessment of the potential risk of loss during that fixed period of time. In other words, the policy period is a material term of the insurance contract. ${ }^{28}$ In exchange for the premium, the insurer agrees to pay for otherwise covered losses if, and only if, they arise from injury or damage happening within the agreed-upon period. ${ }^{29}$

Most CGL policies explicitly limit coverage to bodily injury or property damage that happens during the applicable policy period (often in their "occurrence," "bodily injury," and/or "property damage" definitions). ${ }^{30}$ All sums liability contravenes the plain policy language by requiring policies to pay for damages due to injury or damage happening years or decades before or years or decades after their policy periods. ${ }^{31}$ All sums effectively enables policyholders to rewrite their insurance contracts by forcing insurers to pay for damages that they never agreed to insure, resulting from risks for which they never received premium.

Numerous courts have recognized that all sums liability is inequitable and have observed that the approach is plainly inconsistent with the policy provisions limiting coverage to injury or damage during the policy period. ${ }^{32}$ As New York's highest court succinctly stated:

26. 3-22 New Appleman on Insurance LaW Library Edition § 22.01[4] (Jeffrey E. Thomas ed.) (Library ed. 2015).

27. Id.

28. $I d$.

29. $I d$.

30. See 7 COUCH ON INSURANCE $§ 102: 2$, supra note 10

31. See, e.g., Arco Indus. Corp. v. Am. Motorists Ins. Co., 594 N.W.2d 61, 69 (Mich. Ct. App. 1998) (rejecting "any method of allocation that would require [the insurer] to provide coverage on a joint and several or 'all sums' basis, since that method would require [the insurer] to indemnify [the policyholder] for damage occurring outside the policy period").

32. See, e.g., Olin Corp. v. Ins. Co. of N. Am., 221 F.3d 307, 322-23 (2d Cir. 2000); Spartan Petrol. Co. v. Federated Mut. Ins. Co., 162 F.3d 805, 809 (4th Cir. 1998); Ins. Co. of N. Am. v. Forty-Eight Insulations, Inc., 633 F.2d 1212, 1225 (6th Cir. 1980); Pub. Serv. Co. of Colo. v. Wallis \& Cos., 986 P.2d 924, 938-39 (Colo. 1999) (en banc); Sec. Ins. Co. of Hartford v. Lumbermens Mut. Cas. Co., 826 A.2d 107, 117-18 (Conn. 2003); Outboard Marine Corp. v. Liberty Mut. Ins. Co., 670 N.E.2d 740, 748 (Ill. App. Ct. 1996); Atchison, Topeka \& Santa Fe Ry. Co. v. Stonewall Ins. Co., 71 P.3d 1097, 1132 (Kan. 2003); Mayor of Balt. v. Utica Mut. Ins. Co., 802 A.2d 1070, 1100-01 (Md. Ct. Spec. App. 2002); Bos. Gas Co. v. Century Indem. Co., 910 N.E.2d 290, 302-03 (Mass. 2009); Arco Indus. Corp. v. Am. Motorists Ins. Co., 594 N.W.2d 61, 69-70 (Mich. Ct. App. 1998), aff'd, 617 N.W.2d 330 (Mich. 2000); Domtar, Inc. v. Niagara Fire Ins. Co., 563 N.W.2d 724, 732-33 (Minn. 1997); N. States Power Co. v. Fid. \& Cas. Co. of N.Y., 523 N.W.2d 657, 662 (Minn. 1994); Dutton-Lainson Co. v. Cont'l Ins. Co., 778 N.W.2d 433, 445 (Neb. 2010); EnergyNorth Nat. 
[T] he policies provide indemnification for liability incurred as a result of an accident or occurrence during the policy period, not outside that period. [The policyholder's] singular focus on "all sums" would read this important qualification out of the policies. ${ }^{33}$

Attempting to convert the isolated phrase "all sums," which is often used at the beginning of the insuring agreement in CGL policies ("The [insurance] company will pay on behalf of the insured all sums which the insured shall become legally obligated to pay ... as damages ...."34), into the answer for allocating long-tail claims is akin to "trying to place one's hat on a rack that was never designed to hold it." ${ }^{35}$ The all sums approach serves only to transform each policy into concurrent, rather than consecutive, coverage, with each policy having the same decadeslong policy period. The approach disregards basic tenets of contract construction: to give meaning to all terms of an insurance policy; to harmonize all provisions of the policy and to avoid leaving some provisions without function or sense; and to construe the policy as a whole so as to give every clause meaning if reasonably possible. ${ }^{36}$

\section{All Sums Liability Violates the Doctrine of Reasonable Expectations}

Under the "reasonable expectations" doctrine applied by some courts, ambiguities in an insurance policy are construed against the insurer when the policyholder has an objectively reasonable expectation of coverage. ${ }^{37}$ Ordinarily, policyholders employ this doctrine to avoid the coverage implications of the plain meaning of the language in their policies. In arguing for all sums liability, however, policyholders ignore this doctrine by disregarding the reasonable expectations that arise from the plain meaning of the temporal limitation language in CGL policies.

Numerous state supreme courts have agreed with this observation. For instance, the Massachusetts Supreme Judicial Court observed:

\footnotetext{
Gas, Inc. v. Certain Underwriters at Lloyd's, 934 A.2d 517, 524-27 (N.H. 2007); Owens-Ill., Inc. v. United Ins. Co., 650 A.2d 974, 980 (N.J. 1994); Sharon Steel Corp. v. Aetna Cas. \& Sur. Co., 931 P.2d 127, 142 (Utah 1997); Towns v. N. Sec. Ins. Co., 964 A.2d 1150, 1162-66 (Vt. 2008).

33. Consol. Edison Co. of N.Y. v. Allstate Ins. Co., 774 N.E.2d 687, 695 (N.Y. 2002) (citation omitted).

34. Owens-Ill., Inc., 650 A.2d at 978.

35. Id. at 989 .

36. See, e.g., Liberty Ins. Underwriters, Inc. v. Weitz Co., 158 P.3d 209, 212 (Ariz. Ct. App. 2007); Allianz Ins. Co. v. Guidant Corp., 900 N.E.2d 1218, 1235 (Ill. App. Ct. 2008); Auto-Owners Ins. Co. v. Churchman, 489 N.W.2d 431, 434 (Mich. 1992); Chochorowski v. Home Depot U.S.A., 404 S.W.3d 220, 229-30 (Mo. 2013) (en banc).

37. 1-5 New APPLEMAN ON INSURANCE LAW LiBRARy EDiTiON $\$ 5.05$ (Jeffrey E. Thomas ed.) (2015).
} 
No reasonable policyholder could have expected that a single one-year policy would cover all losses caused by toxic industrial wastes released into the environment over the course of several decades. Any reasonable insured purchasing a series of occurrence-based policies would have understood that each policy covered it only for property damage occurring during the policy year. ${ }^{38}$

The Supreme Court of New Hampshire similarly stated, "we doubt that [the policyholder] could have had a reasonable expectation that each single policy would indemnify [it] for liability related to property damage occurring due to events taking place years before and years after the term of each policy." 39

State supreme courts have particularly highlighted the policyholder's reasonable expectations when the relevant insurance program has significant periods of self-insurance. These courts have observed that the policyholder must reasonably expect to shoulder liability during periods of self-insurance. For instance, the Supreme Court of Utah has held that policyholders must be prepared to pay their fair share for years that they were without insurance, noting that when periods of no insurance reflect a decision to assume or retain a risk, it is reasonable to expect the riskbearer to share in the allocation. ${ }^{40}$ The Utah court cited favorably to the decision by the United States Court of Appeals for the Sixth Circuit in Insurance Co. of North America v. Forty-Eight Insulations, Inc. ${ }^{41}$ That court recognized that it is entirely reasonable for a policyholder to be responsible for injury during periods when it had no insurance, and the all sums scheme would unreasonably provide a manufacturer that had purchased insurance for only one year out of twenty with the same coverage as a manufacturer that had bought coverage every year for two decades. ${ }^{42}$ As the court noted, "[n]either logic nor precedent support

38. Bos. Gas Co. v. Century Indem. Co., 910 N.E.2d 290, 309 (Mass. 2009).

39. EnergyNorth Nat. Gas Inc. v. Certain Underwriters at Lloyd's, 934 A.2d 517, 526 (N.H. 2007) (quoting Pub. Serv. Co. of Colo. v. Wallis \& Cos., 986 P.2d 924, 940 (Colo. 1999)); see also Pub. Serv. Co. of Colo., 986 P.2d at 940 ("[T] insurance policy among 20 or 30 years worth of policies could be expected to be held liable for the entire time period. Nor is it reasonable to expect that a single-year policy would be liable, for example, if the insured carried no insurance at all for the other years covered by the occurrence."); Sec. Ins. Co. of Hartford v. Lumbermens Mut. Cas. Co., 826 A.2d 107, 121 (Conn. 2003) ("Neither the insurers nor the insured could reasonably have expected that the insurers would be liable for losses occurring in periods outside of their respective policy coverage periods."); Mayor of Balt. v. Utica Mut. Ins. Co., 802 A.2d 1070, 1103-04 (Md. Ct. Spec. App. 2002).

40. Sharon Steel Corp. v. Aetna Cas. \& Sur. Co., 931 P.2d 127, 141 (Utah 1997).

41. Id.

42. Ins. Co. of N. Am. v. Forty-Eight Insulations, Inc., 633 F.2d 1212, 1225 (6th Cir. 1980). 
such a result." ${ }^{\text {"43 }}$ Similarly, the Supreme Court of Vermont recognized that where the policyholder is self-insured for any period of time on the risk, it is "fair and reasonable to hold the policyholder responsible for that portion of the total defense and indemnity costs over which he or she chose to assume the risk." 44

\section{All Sums Unjustly Enriches Policyholders}

All sums liability also is inequitable in that it provides a policyholder with premium-free insurance for injury or damage happening outside of the periods for which it had obtained insurance. In other words, the all sums approach unjustly enriches the policyholder. If a policyholder fails to obtain insurance during a period, it must assume responsibility for the risk during that period; otherwise, it is effectively being granted free insurance for periods during which it went "bare." 45

The sheer inequity of the all sums approach is illustrated by the hypothetical situation in which a policyholder is held liable for damage or injury taking place over 30 years, yet did not obtain insurance in 29 out of those 30 years. Under the all sums scheme, the policyholder would be permitted to force the policies in place in that one year to pay for all damages attributable to three decades of damage or injury, with no recourse against other carriers, even though the policyholder only paid premiums for one year of insurance. This result certainly does not correlate the risks insured with the premiums charged. ${ }^{46}$

Several cases have recognized this windfall component of all sums liability as a reason to reject it. Olin Corp. v. Insurance Co. of North America ${ }^{47}$ is a prime example. In Olin, the jury found that environmental soil damage had taken place from 1951 to 1985 . $^{48}$ One insurer, INA, had issued policies with periods from 1956 through 1973. ${ }^{49}$ However, a pollution exclusion barred coverage under the INA policies in effect from 1971 through 1973, and the jury found that policies with periods

\footnotetext{
43. Id.

44. Towns v. N. Sec. Ins. Co., 964 A.2d 1150, 1167 (Vt. 2008) (citing Olin Corp. v. Ins. Co. of N. Am., 221 F.3d 307, 323 (2d Cir. 2000)).

45. Outboard Marine Corp. v. Liberty Mut. Ins. Co., 670 N.E.2d 740, 749 (Ill. App. Ct. 1996) (citing IMCERA Grp., Inc. v. Liberty Mut. Ins. Co., 50 Cal. Rptr. 2d 583, 607 (Cal. Ct. App. 1996)); see also Pub. Serv. Co. of Colo. v. Wallis \& Cos., 986 P.2d 924, 940 (Colo. 1991); Bos. Gas Co. v. Century Indem. Co., 910 N.E.2d 290, 311 (Mass. 2009).

46. Uniroyal, Inc. v. Home Ins. Co., 707 F. Supp. 1368, 1392 (E.D.N.Y. 1988).

47. 221 F.3d 307 (2d Cir. 2000).

48. Id. at 321 .

49. Id.
} 
after 1957 did not cover the soil damage because that damage was not accidental after $1957 .{ }^{50}$ Therefore, although the damage took place over 35 years, INA provided insurance for only two years: 1956 and $1957 .{ }^{51}$ In rejecting the all sums approach in this context, the court noted that permitting the policyholder to recover from a single policy in effect in 1956 or 1957 for all sums arising from its liability as a result of progressive damage taking place between 1956 and 1985 would be tantamount to giving the policyholder a windfall for uncovered damages. $^{52}$

Similarly, in Security Insurance Co. of Hartford v. Lumbermens Mutual Casualty $\mathrm{Co}^{53}$ all sums liability would have required an insurer to pay for injuries taking place during earlier periods covered by lost or destroyed policies that were issued by other carriers. The injuries were alleged to have taken place from March 16, 1951 to May 1, 1996. ${ }^{54}$ However, the policyholder had either lost or destroyed the policies in effect from March 1951 to January $1968 .^{55}$ The all sums scheme would have imposed liability on the remaining carriers for amounts that otherwise would have been allocable to the missing policies. ${ }^{56}$ Rejecting this result, the court apportioned the damages evenly across the entire alleged injury period, with the policyholder responsible for the pro rata share allocated to the periods of the missing policies. ${ }^{57}$

The court declined to impose liability on a single insurer for costs arising outside of its policy period and, thus, during periods for which the insurer received no premium because to do so would result in a windfall and unjustly enrich the policyholder. ${ }^{58}$ The court noted that the policyholder was the party who could have prevented the loss or destruction of the policies, and the remaining insurers bore no blame for that loss or destruction. ${ }^{59}$ Accordingly, the court found that it would be grossly inequitable to make the remaining insurers bear a loss arising from the acts and omissions of a policyholder who had, in essence, rendered itself uninsured for a substantial period. ${ }^{60}$ Numerous courts

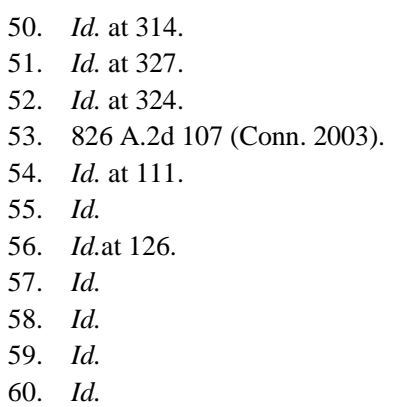


have decried the inequity of the all sums approach on similar grounds. ${ }^{61}$

Not only is the all sums approach inequitable to insurers, but it is ultimately detrimental to policyholders' interests. Facing the prospect of exposure for damages due to injury or damage outside the policy period, the insurers' incentive to insure against future risks is reduced, thereby creating instability in the insurance market. ${ }^{62}$ The uncertainty as to which policy or policies a policyholder will select to pay for a loss under the all sums scheme also creates an unnecessary incentive to litigate. All sums liability also "requires insurers to "factor the costs of uncertain liability into their premiums." "63 The all sums approach forces insurers to consider the possibility of exposure for injuries or damage happening outside of the policy period when calculating premiums, naturally causing premiums to rise. ${ }^{64}$ All sums liability also discourages insurers from providing policies with generous limits due to the increased probability that the policyholder will select such policies under the all sums scheme. ${ }^{65}$

\section{APPLiCATION OF All SUMS NeCESSITATES COMPLEX Litigation TO RESOLVE A WEALTH OF SECONDARY ISSUES, THEREBY NEEDLESSLY CONSUMING JUDICIAL RESOURCES}

Not only does all sums liability distort or ignore policy language, but it also gives rise to a host of complex issues requiring substantial follow-

61. See, e.g., Olin Corp. v. Ins. Co. of N. Am., 221 F.3d 307, 324 (2d Cir. 2000); Spartan Petrol. Co. v. Federated Mut. Ins. Co., 162 F.3d 805, 812-13 (4th Cir. 1998); Ins. Co. of N. Am. v. Forty-Eight Insulations, Inc., 633 F.2d 1212, 1225 (6th Cir. 1980); Nationwide Ins. Co. v. Cent. Mo. Elec. Coop., 278 F.3d 742, 747-48 (8th Cir. 2001); Pub. Serv. Co. of Colo. v. Wallis \& Cos., 986 P.2d 924, 939-40 (Colo. 1999); Sec. Ins. Co. of Hartford v. Lumbermens Mut. Cas. Co., 826 A.2d 107, 121-122 (Conn. 2003); Outboard Marine Corp. v. Liberty Mut. Ins. Co., 670 N.E.2d 740, 748 49 (Ill. App. Ct. 1996); Atchison, Topeka \& Santa Fe Ry. Co. v. Stonewall Ins. Co., 71 P.3d 1097, 1134 (Kan. 2003); Mayor of Balt. v. Utica Mut. Ins. Co., 802 A.2d 1070, 1103 (Md. Ct. Spec. App. 2002); Bos. Gas Co. v. Century Indem. Co., 910 N.E.2d 290, 310 (Mass. 2009); Arco Indus. Corp. v. Am. Motorists Ins. Co., 594 N.W.2d 61, 69 (Mich. Ct. App. 1998), aff'd, 617 N.W.2d 330 (Mich. 2000); Domtar, Inc. v. Niagara Fire Ins. Co., 563 N.W.2d 724, 732 (Minn. 1997); N. States Power Co. v. Fid. \& Cas. Co. of N.Y., 523 N.W.2d 657, 662 (Minn. 1994); Dutton-Lainson Co. v. Cont'l Ins. Co., 778 N.W.2d 433, 445 (Neb. 2010); EnergyNorth Nat. Gas, Inc. v. Certain Underwriters at Lloyd's, 934 A.2d 517, 524-25 (N.H. 2007); Owens-Ill., Inc. v. United Ins. Co., 650 A.2d 974, 989 (N.J. 1994); Mt. McKinley Ins. Co. v. Corning, Inc., 96 A.D.3d 451, $453-54$ (N.Y. App. Div. 2012); Sharon Steel Corp. v. Aetna Cas. \& Sur. Co., 931 P.2d 127, 140 (Utah 1997); Towns v. N. Sec. Ins. Co., 964 A.2d 1150, 1167 (Vt. 2008).

62. Owens-Ill., Inc., 650 A.2d at 990.

63. Bos. Gas Co., 910 N.E.2d at 311 (citing EnergyNorth Nat. Gas, Inc., 934 A.2d at 527).

64. See Michael G. Doherty, Allocating Progressive Injury Liability Among Successive Insurance Policies, 64 U. CHI. L. REV. 257, 269-74 (1997).

65. Id. 
on litigation. Thus, the all sums approach results in a significant waste of valuable judicial resources. Namely, courts following the all sums approach will have to: (1) construe and determine how to apply "prior insurance/non-cumulation" clauses, which appear in many CGL policies; (2) determine how to construe and apply "other insurance" clauses typically found in CGL policies; (3) determine how to construe and apply subrogation clauses and equitable contribution principles between the insurers who are deemed liable; and (4) determine how the policyholder's prior settlements with its insurers will affect reallocation in follow-on litigation among the remaining insurers.

\section{A. Courts Applying All Sums Must Construe and Determine How to Apply "Prior Insurance/Non-Cumulation" Clauses}

All sums liability increases the likelihood that courts will become embroiled in complicated questions regarding the impact of multiple insurance policy provisions on the reallocation of liability among insurers. Among these provisions are "prior insurance/non-cumulation" clauses, which serve to reduce the limits of liability available under policies issued in any given year by amounts that are due for the same loss under policies issued in prior years. ${ }^{66}$ A typical version of one of these clauses, often found in CGL policies, reads as follows:

If a loss covered by this policy is also covered in whole or in part under any other excess policy issued to the Insured prior to the effective date of this policy, the limits of liability as stated in the declarations will be reduced by any amounts due to the Insured under such prior insurance. $^{6}$

A number of courts have found such clauses to be unambiguous and enforceable in the context of all sums liability. ${ }^{68}$

66. See, e.g., Endicott Johnson Corp. v. Liberty Mut. Ins. Co., 928 F. Supp. 176, 181-82 (N.D.N.Y. 1996); Cal. Ins. Co. v. Stimson Lumber Co., No. 01-514-HA, 2004 WL 1173185, at *10 (D. Or. May 26, 2004), aff'd in part, rev'd in part, 325 F. App'x 496, 500 (9th Cir. 2008).

67. See Stimson Lumber Co., 2004 WL 1173185, at *10.

68. See, e.g., Liberty Mut. Ins. Co. v. Treesdale, Inc., 418 F.3d 330, 341-44 (3d Cir. 2005) (enforcing non-cumulation clause); Plantation Pipeline Co. v. Cont'l Cas. Co., No. 1:03-CV-2811WBH, 2008 U.S. Dist. LEXIS 80680, at *7-9 (N.D. Ga. July 8, 2008) (holding that the term "loss" in the non-cumulation clause not ambiguous when viewed in the context of the clause's remaining phrasing); O-I Brockway Glass Container v. Liberty Mut. Ins. Co., No. 90-2797(AET), 1994 WL 910935 , at $* 2$ (D. N.J. Feb. 10, 1994) ("no confusion or ambiguity exists regarding the NonCumulation clause. '[T]he words of an insurance policy should be given their ordinary meaning, and in the absence of an ambiguity, a court should not engage in a strained construction to support the imposition of liability."') (citing Longobardi v. Chubb Ins. Co., 582 A.2d 1257 (N.J. 1990)); Air Prods. \& Chems., Inc. v. Hartford Accident \& Indem. Co., No. 86-7501, 1989 WL 73656, at *2 
Historically, policyholders have attempted to use non-cumulation clauses to support application of all sums liability, arguing that the clause shows that insurers contemplated that their policies covered injury or damage happening outside of their policy periods. ${ }^{69}$ Because courts have deemed non-cumulation clauses to be valid and enforceable, the impact of such clauses under the all sums approach must be determined as well. In fact, as noted, courts have recognized the applicability of these clauses in the all sums context. ${ }^{70}$

\section{B. Courts Must Construe and Apply "Other Insurance" Clauses}

Similarly, courts adopting all sums liability also must determine the effect of "other insurance" clauses. "Other insurance" clauses establish how a loss is to be apportioned among insurers when more than one policy covers the same loss. These clauses typically apply to situations involving concurrent insurance, i.e., where two or more policies insuring the same time period cover the same loss. ${ }^{71}$ Although such clauses should not be relevant in cases involving consecutive insurance for longterm bodily injury or property damage claims, the application of all sums effectively converts consecutive insurance into concurrent insurance by rendering each policy liable for the entirety of a loss (up to its limits). This, in turn, requires courts to analyze the impact of these clauses in the all sums context.

(E.D. Pa. June 30, 1989), aff'd in part, rev'd in part, 25 F.3d 177 (3d Cir. 1994) (holding that there was no basis to fail to refuse the terms of the non-cumulation clause); Stonewall Ins. Co. v. E.I. du Pont de Nemours \& Co., 996 A.2d 1254, 1259 (Del. 2010) (holding that the unambiguous noncumulation clause was properly applied); Hercules, Inc. v. AIU Ins. Co., 784 A.2d 481, 494 (Del. 2001) (enforcing a non-cumulation clause); Mark IV Indus., Inc. v. Lumbermens Mut. Cas. Co., 819 N.Y.S.2d 210, 210 (N.Y. App. Div. 2006) (ordinary language of the non-cumulation provision applied); Hiraldo v. Allstate Ins. Co., 840 N.E.2d 563, 564-65 (N.Y. 2005) (enforcing a noncumulation clause).

69. See, e.g., Hercules, Inc., 784 A.2d at 493-94; Chi. Bridge \& Iron Co. v. Certain Underwriters at Lloyd's, 797 N.E.2d 434, 441 (Mass. App. Ct. 2003).

70. See, e.g., Stonewall Ins. Co., 996 A.2d at 1259-60 ("Under the all sums approach, DuPont may choose a single tower of coverage, applicable to a single year, from which to seek indemnity and defense costs.... The non-cumulation clause does not create an ambiguity which alters this process. ... [I]nterpreting the non-cumulation clause to limit how much DuPont may seek from the selected tower of insurance by subtracting any amounts received by or payable to DuPont from prior excess insurers, is the only proper interpretation.”); Viking Pump, Inc. v. Century Indem. Co., 2 A.3d 76, 126 (Del. Ch. 2009) ("[T]he use of the all sums approach with faithful application of the Non-Cumulation and Prior Insurance Provisions accomplishes many of the same policy purposes as the pro rata method.").

71. See, e.g., Keene Corp. v. Ins. Co. of N. Am., 667 F.2d 1034, 1051 (D.C. Cir. 1981) ("When more than one policy applies to a loss, the 'other insurance' provisions of each policy provide a scheme by which the insurers' liability is to be apportioned."); Schoenecker v. Haines, 277 N.W.2d 782, 783-84 (Wis. 1979). 
There are three general categories of "other insurance" clauses: "escape clauses," which seek to avoid all liability; "pro rata clauses," which limit the liability of an insurer to a proportion of the total loss; and "excess clauses," which provide that the insurance will only be excess of other insurance. ${ }^{72}$

One typical "escape clause" provides, "If with respect to loss and ultimate net loss covered hereunder, the insured has other insurance, whether on a primary, excess, or contingent basis, there shall be no insurance afforded hereunder as respects loss and ultimate net loss ...."73 When more than one policy is involved in a claim, such a clause would shift all responsibility for the claim onto the other involved policy or policies. However, if all of the competing policies contain an escape clause, applying those clauses would leave the policyholder with no coverage at all.

A typical excess "other insurance" clause provides, "If other collectible insurance with any other insurer is available to the Insured covering a loss also covered hereunder ... the insurance hereunder shall be in excess of, and shall not contribute with, such other insurance." When more than one policy is involved in a claim, this clause would require the other policies to pay first and exhaust their limits before the policy containing the excess clause is required to pay anything. A problem arises, however, when two triggered policies each contain such an excess clause.

Still other policies contain a pro rata "other insurance" clause. A typical version of this type of clause provides:

If the insured has other insurance against a loss covered by ... this policy the company shall not be liable under this policy for a greater proportion of such loss than the applicable limit of liability stated in the declarations bears to the total applicable limit of all valid and collectible insurance against such loss. ${ }^{75}$

When multiple policies are involved in a dispute, they will often

72. Fireman's Fund Ins. Co. v. Empire Fire \& Marine Ins. Co., 155 F. Supp. 2d 429, 431 n.3 (E.D. Pa. 2001); Nationwide Ins. Co. v. Horace Mann Ins. Co., 759 A.2d 9, 11 (Pa. Super. Ct. 2000).

73. See, e.g., Westinghouse Elec. Corp. v. Am. Home Assur. Co., Nos. A-6706-01T5, A-672001T5, 2004 WL 1878764, at *15-16 (N.J. Super. Ct. Law Div. July 8, 2004); 8a-204Af APPLEMAN ON INSURANCE LAW \& PRACTICE ARCHIVE $\$ 4910$ (2013), LexisNexis.

74. See, e.g., State Farm Fire \& Cas. Co. v. LiMauro, 482 N.E.2d 13, 19 (N.Y. 1985).

75. Econ. Fire \& Cas. Co. v. Western States Mut. Ins. Co., 198 N.E.2d 723, 727 (Ill. App. Ct. 1964); see, e.g., W9/PHC Real Estate LP v. Farm Family Cas. Ins. Co., 970 A.2d 382, 394 (N.J. Super. Ct. App. Div. 2009) (citing 15 COUCH ON INSURANCE 3d § 219:27 (2005)). 
contain competing clauses, requiring a court to reconcile them. ${ }^{76}$ In such situations a court is likely to be presented with policies containing a combination of different types of "other insurance" clauses. Reconciling and applying these clauses correctly is a highly burdensome and laborintensive task, particularly in the context of larger insurance programs and long-tail claims covering extended periods.

\section{Courts Must Determine How to Construe Subrogation Clauses and How to Apply Equitable Subrogation and Contribution Rights}

When all sums liability is imposed, the policyholder's initial suit determines the policies from which the policyholder is entitled to select. The selected insurer(s) must then initiate a subsequent suit or pursue continuing litigation to obtain contribution from the other insurers whose policies were triggered, but whose policies the policyholder did not choose. ${ }^{77}$ Rather than remedying the allocation problem, the all sums scheme merely postpones it by improvidently dividing what should be a single piece of litigation into two separate suits or at least a single prolonged suit involving two phases. $^{78}$ The follow-on contribution proceedings involve issues identical to those at issue in the initial coverage proceeding, compounding the resultant judicial inefficiency. ${ }^{79}$

Moreover, subsequent actions among insurers are far more complicated than the simple, straightforward application of pro rata allocation. In such actions, courts have tended to adopt one of two approaches: (1) contribution or (2) subrogation.

Equitable contribution grants an insurer who has paid a claim the right to recover from a co-insurer where both insurers were obligated to indemnify or defend the claim and where the co-insurer did not share, or did not sufficiently share, in doing so. ${ }^{80}$ Equitable subrogation also arises when one person has involuntarily paid a debt for which another

76. See, e.g., Planet Ins. Co. v. Ertz, 920 S.W.2d 591, 595 (Mo. Ct. App. 1996) (Missouri law requires a court to analyze the other insurance clauses in the policies before it "for repugnancy and conflicts, and dissimilar types of clauses are analyzed for specificity.").

77. Contribution claims require a subsequent trial because, as a rule, the right to contribution is not enforceable until the party seeking contribution has paid more than its share of a common obligation. See 18 AM. JuR. 2d Contribution § 11 (2015).

78. Bos. Gas Co. v. Century Indem. Co., 910 N.E.2d 290, 311 (Mass. 2009) (citing EnergyNorth Nat. Gas, Inc. v. Certain Underwriters at Lloyd's, 934 A.2d 517, 527 (N.H. 2007)).

79. Olin Corp. v. Ins. Co. of N. Am., 221 F.3d 307, 323 (2d Cir. 2000) (quoting In re Prudential Lines Inc., 158 F.3d 65, 85 (2d Cir. 1998)).

80. 8a-204Af APPleman ON Insurance LAW \& PRACTICE ARChive § 4921 (2013), LexisNexis. 
was liable and which, in equity, should have been paid by the latter. ${ }^{81}$

Contractual subrogation also may arise from a contract that grants the right to pursue reimbursement from a third party in exchange for payment of a loss. ${ }^{82}$ CGL policies are likely to contain subrogation clauses. A typical subrogation clause provides:

The Insurer shall be subrogated to all of the "Insured's" rights of recovery with respect to any payment made under this Policy. In this regard, the "Insured" shall execute any documentation required to enforce such rights and shall co-operate in all respects with the Insurer to assist in the enforcement of such rights. The "Insured" shall do nothing to interfere with or impair the Insurer's right of subrogation. ${ }^{83}$

Because of their nature, excess policies are likely to contain more complex subrogation clauses. One such clause provides:

Because this policy affords excess coverage, the Insured's right of recovery cannot always be exclusively subrogated to the Company. It is therefore agreed that the company shall act in concert with all other interests concerned, including the Insured, in the enforcement of any subrogation rights or in the recovery of amounts by any other means. The apportioning of any amounts so recovered shall follow in the principle that any interest, including the Insured, that shall have paid an amount over and above any payment under this policy shall first be reimbursed up to the amount paid by such interest; the Company shall then be reimbursed out of any balance then remaining up to the amount paid as the result of loss covered under this policy; and lastly, the interests, including the Insured, of whom this coverage is in excess are entitle[d] to claim any residue remaining. Expenses and costs necessary to the recovery of any such amount shall be apportioned between the interests concerned, including the Insured, in the ratio of their respective recoveries or in the event of a totally unsuccessful attempt to recover, in the ratio of the respective amounts sought to be recovered. ${ }^{84}$

While a paying insurer holds its own independent contribution rights, in the case of either equitable or contractual subrogation, "the insurer stands in the shoes of the insured, obtaining only those rights held by the insured against a third party, subject to any defenses held by the third

81. Cont'l Cas. Co. v. N. Am. Capacity Ins. Co., 683 F.3d 79, 85 (5th Cir. 2012) (quoting MidContinent Ins. Co. v. Liberty Mut. Ins. Co., 236 S.W.3d 765, 774 (Tex. 2007)).

82. Id.

83. Joseph D. JeAn \& Matthew D. StockWEll, Fall 2014-97 Appleman: CurRent CRITICAL ISSUES IN INSURANCE LAW II (2014), LexisNexis.

84. See, e.g., Lloyds of London Policy Form CL010 (09/02), LLOYDS OF LONDON, $\mathrm{ftp}: / / 139.142 .150 .99 /$ bajaweb/policy/forms/CL010.pdf (last visited Sept. 19, 2015). 
party against the insured." 85

Thus, in addressing follow-on contribution claims, a court must first concern itself with the distinctions between the paying insurer(s) claims for recovery from non-selected insurers under theories of equitable contribution, equitable subrogation, and contractual subrogation. Then, the court must consider the bases for such claims under the applicable law in order to determine the extent to which the paying insurer(s) can enforce contribution or subrogation rights against insurers who were not selected to pay. For example, the court may be required to determine the extent to which the controlling law allows paying insurers to assert either contribution or subrogation claims against settled insurers, and/or the extent to which that body of law allows paying excess insurers to assert contribution or subrogation claims against primary insurers.

Courts have noted the difficulties in implementing both contribution and subrogation. As one court observed, "Even a cursory reading of judicial decisions in this area reveals a great deal of confusion in the courts about the equitable doctrines of subrogation and contribution, their differences and their appropriate applications to various factual circumstances." 86 The relevant principles often are misunderstood and, many times, the doctrines are used interchangeably. In fact, it is "difficult to think of two legal concepts that have caused more confusion and headache for both courts and litigants than have contribution and subrogation." 87

Moreover, the utility of contribution actions to resolve the inequities brought about by the application of all sums is largely illusory, in substantial part because contribution generally is not available against the policyholder for uninsured periods. Any recovery in a contribution action also may be impossible because, for example, the insurer who issued other triggered policies is insolvent and unable to pay. ${ }^{88}$ The all

85. Cont'l Cas. Co., 683 F.3d at 85 (quoting Mid-Continent Ins. Co., 236 S.W.3d at 774).

86. U.S. Fid. \& Guar. Co. v. Federated Rural Elec. Ins. Corp., 37 P.3d 828, 832 (Okla. 2001).

87. Id. (quoting Fireman's Fund Ins. Co. v. Md. Cas. Co., 77 Cal. Rptr. 2d 296, 302 (Cal. Ct. App. 1998)).

88. Olin Corp. v. Ins. Co. of N. Am., 221 F.3d 307, 324 (2d Cir. 2000) ("Allocation is appropriate to prevent [the policyholder] from imposing liability on [the insurer] for injuries that occurred during those periods and arose largely from accidents during these periods in which [the policyholder] was not paying for coverage. In the context of this litigation, moreover, allocation serves the cause of efficiency. Any 'contribution action' [the insurer] might be entitled to bring under the joint and several approach, against [the policyholder] for the latter's period of selfinsurance ... would involve many of the same issues that arose in this proceeding. The duplication of effort and expense is unnecessary."); see also In re Prudential Lines Inc., 158 F.3d 65, 85 (2d Cir. 1998) ("The courts that have endorsed allocation when the loss is paid have generally been motivated by considerations of equity and policy, rather than contract wording. First, these courts 
sums approach thus unfairly forces solvent carriers to assume the burden of the policyholder's business decision to self-insure or under-insure particular time periods and to absorb the consequences of the insolvencies of other insurers chosen by the policyholder. Equity dictates that "the risk of such defalcation fall on the insured, which purchased the defaulting insurer's policy, rather than on another insurer which was a stranger to the selection process." $" 89$

\section{Courts Must Determine How a Policyholder's Prior Settlements with Insurers Impact “All Sums” Liability}

The all sums scheme also requires a court to grapple with how to integrate credits for settlements by other carriers into the follow-on contribution or subrogation proceedings. These issues include such questions as: (1) the impact of a policyholder's decision to settle with carriers that issued policies in years other than the one it now wants to choose $;^{90}$ (2) the amounts of the settlement credits to be provided $;{ }^{91}$ and (3) the impact of the scope of the releases in the settlements on the scope of, and responsibility for, settlement credits. ${ }^{92}$ Resolution of these issues will likely entangle courts in time-consuming discovery disputes concerning confidential settlement negotiations and settlement agreements in order to unravel the precise nature and effect of prior settlements and their impact upon the selected insurers' ultimate obligations. Thus, all sums liability creates subsequent, complex apportionment and reallocation problems without any clear resolution. It serves only to increase litigation costs, while providing no guidance as to the solutions for the conundrums it raises. ${ }^{93}$ While purporting to resolve the allocation issue, all sums merely postpones and complicates it.

\footnotetext{
have sought to ensure that a single insurer underwriting a small proportion of the risk does not get saddled with the full loss, ... a loss that may prove uncollectible from other companies."); Bos. Gas Co. v. Century Indem. Co., 910 N.E.2d 290, 311 (Mass. 2009).

89. Olin Corp., 221 F.3d at 323.

90. See, e.g., Koppers Co. v. Aetna Cas. \& Sur. Co., 98 F.3d 1440, 1452 (3d Cir. 1996); Mass. Elec. Co. v. Commercial Union Ins., No. 9900467B, 2005 WL 3489874, at *2 (Mass. Super. Ct. Oct. $25,2005)$.

91. See, e.g., Goodrich Corp. v. Commercial Union Ins. Co., Nos. 23585, 23586, 2008 WL 2581579, at *7-8 (Ohio Ct. App. June 30, 2008).

92. See, e.g., Weyerhaeuser Co. v. Commercial Union Ins. Co., 15 P.3d 115, 126-27 (Wash. 2000).

93. See Pub. Serv. Co. of Colo. v. Wallis \& Cos., 986 P.2d 924, 939-40 (Colo. 1999).
} 


\section{Pro Rata By Time-ON-THE-Risk Allocation Avoids All of the PITFALLS OF ALL SUMS LIABILITY}

Adopting the pro rata by time-on-the-risk method for allocating losses resulting from long-tail claims, rather than applying the "intuitively suspect"94 all sums scheme, comports with the relevant policy language and facilitates a far more equitable result. The pro rata approach divides the total damages by the number of years during which the injury or damage took place, thus allocating the damages evenly to each year, unless any interested party can rebut the presumption that the injury or damage happened evenly over the relevant period. ${ }^{95}$ The pro rata approach is consistent with the application of a continuous trigger, ${ }^{96}$ since both acknowledge the inherent uncertainty as to what actually transpired during any particular policy period with respect to long-tail claims. $^{97}$ Pro rata allocation relieves policyholders of their burden to prove the amount of injury or damage that happened in each policy period while simultaneously deferring to the terms of the policies' respective insuring agreements. ${ }^{98}$

The pro rata by time-on-the-risk method is also consistent with the temporal limitations in CGL policies, which plainly limit coverage to damage or injury taking place during the policy period. This stands in stark contrast to all sums liability, which ignores this fundamental aspect of these policies. ${ }^{99}$ Thus, courts rejecting all sums liability have

94. Owens-Ill., Inc. v. United Ins. Co., 650 A.2d 974, 989 (N.J. 1994) ("the argument that all sums to be assessed because of long-term exposure to asbestos could have been established in any one of the policy years is intuitively suspect ...").

95. See, e.g., Ins. Co. of N. Am. v. Forty-Eight Insulations, Inc., 633 F.2d 1212, 1224-25 (6th Cir. 1980) (allowing any party to prove specific years of exposure); Sec. Ins. Co. of Hartford v. Lumbermens Mut. Cas. Co., 826 A.2d 107, 121 (Conn. 2003); Outboard Marine Corp. v. Liberty Mut. Ins. Co., 670 N.E.2d 740, 749 (Ill. App. Ct. 1996); Bos. Gas Co. v. Century Indem. Co., 910 N.E.2d 290, 312 (Mass. 2009); Arco Indus. Corp. v. Am. Motorists Ins. Co., 594 N.W.2d 61, 69 (Mich. Ct. App. 1998), aff'd, 617 N.W.2d 330 (Mich. 2000).

96. See, e.g., Outboard Marine Corp., 670 N.E.2d at 748; U.S. Gypsum Co. v. Admiral Ins. Co., 643 N.E.2d 1226, 1257 (Ill. App. Ct. 1994); EnergyNorth Nat. Gas, Inc. v. Certain Underwriters at Lloyd's, 934 A.2d 517, 526 (N.H. 2007).

97. Mayor of Balt. v. Utica Mut. Ins. Co., 802 A.2d 1070, 1104 (Md. Ct. Spec. App. 2002).

98. See Doherty, supra note 64, at 278-79.

99. See, e.g., Pub. Serv. Co. of Colo. v. Wallis \& Cos., 986 P.2d 924, 940 (Colo. 1999) (where continuous trigger rule applies, courts "should make a reasonable estimate of the portion of the 'occurrence' that is fairly attributable to each year by dividing the total amount of liability by the number of years at issue"); Arco Indus. Corp., 594 N.W.2d at 69 (pro rata allocation is the "logical corollary" of the occurrence policy covering damage sustained during, but not outside, the policy period); EnergyNorth Nat. Gas, Inc., 934 A.2d at 526 (deeming "pro rata allocation to be superior to joint and several allocation because it is more consistent" with the continuous trigger theory); Consol. Edison Co. v. Allstate Ins. Co., 774 N.E.2d 687, 695 (N.Y. 2002) ("Pro rata allocation . . . is 
concluded that, where the policyholder is self-insured for any period of time on the risk, it is fair and reasonable to hold the policyholder accountable for that portion of the total costs allocable to the self-insured period. ${ }^{100}$ Pro rata allocation "forces companies to internalize part of the costs of long-tail liability and creates incentives for companies to minimize environmental carelessness by not permitting a policyholder who chooses not to be insured for part of the long-tail injury period to recover as if the policyholder had been fully covered for that period."101

Pro rata allocation also presents several other advantages over all sums liability. These advantages include "spreading the risk to the maximum number of carriers, easily identifying each insurer's liability through a relatively simple calculation, and reducing the necessity for subsequent indemnification actions between and among the insurers."102 Pro rata allocation avoids unjustly saddling one insurer with the entirety of the policyholder's loss, and it eliminates the risk that any contribution or subrogation rights will be reduced or abrogated due to uninsured periods and insurer insolvencies. ${ }^{103}$ In doing so, the pro rata approach "promotes judicial efficiency, engenders stability and predictability in the insurance market, provides incentive for responsible commercial behavior, and produces an equitable result."104

Last but not least, unlike the myriad problems inherent in the all sums approach, pro rata by time-on-the-risk allocation is straightforward to implement. With "intuitive, commonsense appeal," its inherent simplicity promotes predictability, minimizes the need for protracted, complex follow-on litigation, and ultimately reduces premium rates. ${ }^{105}$ "Once a court determines the scope of the progressive injury ... it can

\footnotetext{
consistent with the language of the policies" which "provide indemnification for liability incurred as a result of an accident or occurrence during the policy period, not outside that period.").

100. See, e.g., Outboard Marine Corp., 670 N.E.2d at 748 (allocating damages to the policyholder for the years during which it carried no insurance "is the only fair approach"); Towns v. N. Sec. Ins. Co., 964 A.2d 1150, 1167 (Vt. 2008) (holding policyholder responsible for all costs when self-insured).

101. EnergyNorth Nat. Gas, Inc., 934 A.2d at 526.

102. Towns v. N. Sec. Ins. Co., 964 A.2d 1150, 1166 (Vt. 2008).

103. Olin Corp. v. Ins. Co. of N. Am., 221 F.3d 307, 323 (2d Cir. 2000); Bos. Gas Co. v. Century Indem. Co., 910 N.E.2d 290, 311 (Mass. 2009); see also In re Prudential Lines Inc., 158 F.3d 65, 85 (2d Cir. 1998) ("these courts see allocation as the most efficient way to assign liability among policies, reasoning that any contribution proceeding will involve many of the same issues that are raised in the initial liability proceeding, and that it is more efficient to deal with these issues in a single proceeding").

104. Bos. Gas Co., 910 N.E.2d at 311.

105. Arco Indus. Corp., 594 N.W.2d at 70 (citing Michael G. Doherty, Allocating Progressive Injury Liability Among Successive Insurance Policies, 64 U. CHI. L. REV. 257, 281-83 (1997)).
} 
readily allocate the damages among the triggered policies." ${ }^{\text {"106 }}$ Provisions such as the non-cumulation clause would not even apply and need not be analyzed under pro rata allocation, since under this approach no one policy year is paying for the same damages, or the same loss, as policies in other years. Thus, under the pro rata approach such clauses are not even implicated. ${ }^{107}$ Several jurisdictions have adopted pro rata allocation in light of these apparent advantages and its deference to policy language. ${ }^{108}$

106. Id.

107. See, e.g., Spaulding Composites Co. v. Aetna Cas. \& Sur. Co., 819 A.2d 410, 422 (N.J. 2003 ) (explaining that once a court adopts pro rata allocation, the non-cumulation clause "drops out" of the policy).

108. See, e.g., Nationwide Ins. Co. v. Cent. Mo. Elec. Coop., 278 F.3d 742, 748 (8th Cir. 2001); Olin Corp., 221 F.3d at 324-25; Spartan Petrol. Co. v. Federated Mut. Ins. Co., 162 F.3d 805, 812 (4th Cir. 1998); Gulf Chem. \& Metallurgical Corp. v. Associated Metals \& Minerals Corp., 1 F.3d 365, 371-72 (5th Cir. 1993); Commercial Union Ins. Co. v. Sepco Corp., 765 F.2d 1543, 1544 (11th Cir. 1985); Ins. Co. of N. Am. v. Forty-Eight Insulations, Inc., 633 F.2d 1212, 1224-25 (6th Cir. 1980); Pub. Serv. Co. of Colo. v. Wallis \& Cos., 986 P.2d 924, 939-40 (Colo. 1999); Sec. Ins. Co. v. Lumbermens Mut. Cas. Co., 826 A.2d 107, 123 (Conn. 2003); Sentinel Ins. Co. v. First Ins. Co. of Haw., Ltd., 875 P.2d 894, 918 (Haw. 1994); Outboard Marine Corp. v. Liberty Mut. Ins. Co., 670 N.E.2d 740, 748 (Ill. App. Ct. 1996); Atchison, Topeka \& Santa Fe Ry. Co. v. Stonewall Ins. Co., 71 P.3d 1097, 1134 (Kan. 2003); Aetna Cas. \& Sur. Co. v. Commonwealth, 179 S.W.3d 830, 842 (Ky. 2005); Norfolk S. Corp. v. Cal. Union Ins. Co., 859 So. 2d 201, 208 (La. Ct. App. 2003); Mayor of Balt. v. Utica Mut. Ins. Co., 802 A.2d 1070, 1101-04 (Md. Ct. Spec. App. 2002); Bos. Gas Co., 910 N.E.2d at 312; Arco Indus. Corp., 594 N.W.2d at 69; N. States Power Co. v. Fid. \& Cas. Co. of N.Y., 523 N.W.2d 657, 662-64 (Minn. 1994); Mallinckrodt Inc. v. Cont'l Ins. Co., No. 05CC001214, 2012 WL 5869877 (Mo. Cir. Ct. of St. Louis Cty. Nov. 9, 2012); Dutton-Lainson Co. v. Cont'l Ins. Co., 778 N.W.2d 433, 445 (Neb. 2010); EnergyNorth Nat. Gas, Inc. v. Certain Underwriters at Lloyd's, 934 A.2d 517, 527 (N.H. 2007); Owens-Ill., Inc. v. United Ins. Co., 650 A.2d 974, 993-95 (N.J. 1994); Consol. Edison Co. of N.Y., Inc. v. Allstate Ins. Co., 774 N.E.2d 687, 694-95 (N.Y. 2002); Sharon Steel Corp. v. Aetna Cas. \& Sur. Co., 931 P.2d 127, 140-42 (Utah 1997); Towns v. N. Sec. Ins. Co., 964 A.2d 1150, 1167 (Vt. 2008). 